\title{
The Effect of the Three-Field Crop Rotation System and Cereal Monoculture on Grain Yield and Quality and the Economic Efficiency of Durum Wheat Production
}

\author{
Andrzej Woźniak ${ }^{1}$, Anna Nowak ${ }^{2 *}$, Dorota Gawęda ${ }^{1}$ \\ ${ }^{1}$ University of Life Sciences in Lublin, Faculty of Agrobioengineering, Department of Herbology and Plant Cultivation \\ Techniques, Akademicka 13, 20-950 Lublin, Poland \\ ${ }^{2}$ University of Life Sciences in Lublin, Faculty of Agrobioengineering, Department of Economics and Agribusiness, \\ Akademicka 13, 20-950 Lublin, Poland
}

Received: 3 February 2021

Accepted: 18 March 2021

\begin{abstract}
A small-plot field experiment was performed to evaluate the effect of the three-field system of crop rotation and cereal monoculture on grain yield and quality and the economic effectiveness of durum wheat production. The experimental factors were tillage systems (TS): 1) conventional tillage (CT), 2) reduced tillage (RT) and 3) no tillage (NT); crop sequence (CS): 1) crop rotation A: pea - durum wheat - spring barley; 2) crop rotation B: pea - spring wheat - durum wheat; 3) cereal monoculture (CM): spring barley - spring wheat - durum wheat. The highest yield of durum wheat (Triticum durum Desf.) was recorded for crop rotation A, a significantly lower one for crop rotation B, and the lowest for cereal monoculture. The grain yield in CT was also higher than in NT (by 17.3\%). The wet gluten content in grain, sedimentation index and the grain weight per volume were to a larger extent dependent on CS than TS, while the content of protein in grain - on TS rather than on CS. From the economic point of view, the best results were recorded for $\mathrm{CT}$ of wheat and for crop rotation A: pea - durum wheat spring wheat. The study also showed that monoculture was not profitable, even with an NT system.
\end{abstract}

Keywords: cropping system, economic results, grain, quality, soil tillage, Triticum durum

\section{Introduction}

Reduced tillage and no-tillage systems are a domain of present-day agriculture [1-3]. This is due to production and economic respects, while the grain

*e-mail: anna.nowak@up.lublin.pl yield obtained from such systems is only slightly lower than that obtained from cost-consuming conventional tillage [4-7]. Hernanz et al. [8] demonstrated that the energy efficiency of wheat cultivation is higher under no-tillage than under reduced and conventional tillage systems. Unfortunately, such solutions also have many drawbacks. These include: larger weed cover and compensation of a few species of weeds, and, as a 
consequence, the necessity to apply numerous herbicide treatments [9-11]. The yield and quality of grain are also affected by pathogenic fungi that cause the root rot disease and fusariosis usually accompanying cereal crop rotation [12-15]. The largest exposure to such pathogens is observed in fields where wheat or barley is sown alternately on a continuous basis [16]. A result may be a decreased grain yield, and further, deteriorated technological quality of grain mainly a reduction in grain weight per volume, a high share of small and poorly filled grains, low grain plumpness and uniformity and a higher content of ash in grain $[3,17]$. These changes are only partly prevented by a high dosage of fertilizers and an increased number of plant protection procedures, which, in a longterm perspective, leads to an increase in the costs of production [2-6].

Apart from the yield level and quality of grain, an important aspect of cereal production is economic efficiency [18-20]. However, most of the available studies focus only on high yield production of wheat grain and do not take into account the significance of economic efficiency [21]. Meanwhile, as emphasized by Jat et al. [22] and Falcone et al. [23], the application of various tillage technologies can affect the level of profitability due to the differentiation of crops and costs of production. In the market economy setting, decisions related to the selection of the production structure and tillage method are not made based on yield and quality only but they also take economic results into account [24]. The costs of production are a fundamental factor determining the economic efficiency of production; hence their level should be subject to review, as well as to detailed planning and control [25]. This justifies the need for undertaking comprehensive studies on the effect of crop rotation and tillage systems on grain yield and quality, taking the economic aspects of production into account.

The studies aimed at evaluating the yield level and technological quality of grain as well as the economic efficiency of durum wheat cultivation in three-field crop rotation and long-term cereal monoculture. Agriculture is a sector of economy that is particularly exposed to risk. Farmers, making decisions related to production, do not know the consequences of such decisions. The studies constitute an attempt at filling the information gap regarding knowledge of possible economic effects of durum wheat production using different soil tillage systems and different crop sequences. Producers of durum wheat are now under pressure of maintaining economic efficiency given the environmental limitations, high costs of production and increasing quality requirements in the pasta industry. Therefore, the development of a cropping strategy ensuring maximum profitability is of key importance. In spite of a its relatively small low production area, of production, durum wheat is an economically important crop due to its unique characteristics and end products [26].

\section{Materials and Methods}

\section{Location, Experiment Design and Habitat Conditions}

As part of a long-term field experiment, carried out from 1988, in 2019 the effect of long-term varied crop rotation and different tillage systems on grain yield and quality and on the economic efficiency of durum wheat (Triticum durum Desf.) production was evaluated. The experiment was performed using the split plot method in three replications. For each crop rotation, $75 \times 6 \mathrm{~m}$ plots were split into three sub-plots on which conventional tillage (CT), reduced tillage (RT) and no-tillage (NT) systems were applied. For crop rotation A the planned cropping sequence was: pea - durum wheat - spring barley; for crop rotation B: pea - spring wheat - durum wheat; and for cereal monoculture (CM): spring barley - spring wheat - durum wheat. The soil tillage model for all sites is presented in Table 1 .

The experiment was founded on Rendzic Phaeozem [27] soil containing $24.7 \%$ loamy intrusions and $13.2 \%$ dusty intrusions. The soil is characterized by an alkaline reaction and a high content of assimilable phosphorus, potassium and an average content of magnesium.

The vegetation period, expressed as a number of days with average daily temperatures exceeding $+5^{\circ} \mathrm{C}$, starts at the end of March and the beginning of April and continues for approximately 210-215 days. In the warm season (May till October), the precipitation total is on average $430 \mathrm{~mm}$, while in the cold season (November till April) it is $210 \mathrm{~mm}$. The average ambient temperature from May to October was $+15.1^{\circ} \mathrm{C}$, whereas from November to April it was $+1.5^{\circ} \mathrm{C}$. The highest precipitation totals are recorded in June (on average $71 \mathrm{~mm})$ and in July $(83 \mathrm{~mm})$, whereas the highest

Table 1. Soil tillage scheme.

\begin{tabular}{|c|c|c|c|}
\hline \multirow{2}{*}{ Tillage programme } & \multicolumn{2}{|c|}{ Soil tillage } \\
\cline { 2 - 4 } & CT & RT & NT \\
\hline \multirow{2}{*}{ Post-harvest } & $\begin{array}{c}\text { Shallow ploughing, depth } 10-15 \mathrm{~cm}, \\
2 \times \text { harrowing }\end{array}$ & Cultivator + harrow & glyphosate $360 \mathrm{~g} \mathrm{~L}^{-1}, 4 \mathrm{~L} \mathrm{ha}^{-1}$ \\
\hline Pre-winter & Deep pre-winter ploughing, $25 \mathrm{~cm}$ & Cultivator & \\
\hline Spring & \multicolumn{2}{|c|}{ Tillage unit composed of a cultivator, a string roller and a harrow } \\
\hline
\end{tabular}


ambient temperatures in July $\left(+17.4^{\circ} \mathrm{C}\right)$ and in August $\left(+16.6^{\circ} \mathrm{C}\right)$.

Durum wheat 'Duromax' was sown in the first decade of April with the sowing density of 500 seeds per $\mathrm{m}^{2}$. A dose of $120 \mathrm{~kg} \mathrm{ha}^{-1} \mathrm{~N}, 39 \mathrm{~kg} \mathrm{ha}^{-1} \mathrm{P}$ and $99 \mathrm{~kg} \mathrm{ha}^{-1} \mathrm{~K}$ was used for this cereal. Nitrogen was used in three split doses: $60 \mathrm{~kg} \mathrm{ha}^{-1}$ prior to sowing, $40 \mathrm{~kg} \mathrm{ha}^{-1}$ at the tillering stage and $20 \mathrm{~kg} \mathrm{ha}^{-1}$ at the shooting stage. On the other hand, phosphorus and potassium fertilizers were used in a single dose before wheat sowing. The following weed control herbicide mix was used: iodosulfuron-methyl-sodium + amidosulfuron (0.1 L ha $\left.\mathrm{La}^{-1}\right)$ and fenoxaprop-P-ethyl $\left(1 \mathrm{~L} \mathrm{ha}^{-1}\right)$ at the tillering stage $(22-23$ in the $\mathrm{BBCH}$ scale) [28]. A propiconazole + fenpropidin mixture $\left(0.8 \mathrm{~L} \mathrm{ha}^{-1}\right)$ protected the wheat against fungal diseases at the shooting stage (BBCH 31-32).

The following characteristics were evaluated in the experiment: grain yield $\left(\mathrm{t} \mathrm{ha}^{-1}\right)$, quality characteristics, i.e. total protein content $(\%)$, wet gluten content $(\%)$, and the Zeleny sedimentation index $(\mathrm{mL})$. The content of starch in grain (\%) was assessed by means of NIRS (near infrared reflectance spectroscopy), whereas grain weight per volume $\left(\mathrm{kg} \mathrm{hL}^{-1}\right)$ was measured using a density meter with the volume equivalent to $1 \mathrm{~L}$ cylinder.

The results were calculated using the statistical analysis of variance (ANOVA), whereas the significance of differences between the mean values for the cropping system (CS) and tillage systems (TS) and the interaction effects (CS x TS) were estimated by means of Tukey's HSD test, $\mathrm{p}<0.05$.

\section{Economic Efficiency}

For the economic assessment of durum wheat production involving various soil tillage systems and different crop sequences, economic categories were used in compliance with the income statement adopted by the European Farm Accountancy Data Network (FADN). To this end, the gross margin and income from the activity were used. The gross margin was calculated as an annual value of production per 1 hectare of crops less direct costs of such crop production [29]. The value of production is determined according to market selling prices. The rule regulating the inclusion of certain components of cost components in direct costs are meeting the following three conditions concurrently: 1) these costs can be clearly assigned to a specific activity, 2) their size is proportional to the scale of production, 3) they have a direct impact on the size (volume and value) of production.

The direct costs of crop production include: the cost of seeds, fertilizers, plant protection products and growth regulators and specific costs that are of direct relevance to a specific activity and to improving the quality and value of the final product [30]. On the other hand, income from the activity is the margin after deducting all the components of overall costs (direct and indirect costs) from the value of production. The calculation method for of these categories is presented below:

Gross Margin $=$ production value - direct costs

Income from the activity $=$ production value - total costs (direct and indirect)

Indirect costs include actual indirect costs (such as fuel, services, insurance and cost of external factors) and estimated indirect costs (depreciation). Support for agricultural producers' incomes includes subsidies [31].

This study calculates income from the activity including payments, i.e. including single area payment (SAP), the payments to seed material and the refund of excise tax on fuel used for agricultural purposes. The analysis is supplemented by the production profitability ratio. The ratio was calculated as a relation of the value of production (including the payments) to total cost incurred and it was expressed in \%. If its value is lower than 100 , the production is unprofitable, while if it is higher than 100, the profitability is higher (the higher the result, the better the profitability is) [32].

\section{Results and Discussion}

Grain yield and quality. The highest yield of durum wheat was recorded for crop rotation A. It was significantly lower for crop rotation B (by $18.2 \%$ ), while the lowest yield was observed for cereal monoculture (by 33.6\%). Also, the studies by Smagacz et al. [33] demonstrate that the grain yield of wheat grown after cereals was lower than that obtained for wheat grown otherwise than in cereal monoculture. The studies by Morrison et al. [34] show that the yield of wheat under conventional tillage was $22 \%$ higher for crop rotation than for cereal monoculture.

The grain yield in CT was also higher (by 17.3\%) than in NT - Table 2.

Numerous studies [3, 13, 16, 35] indicate that crop rotation, and in particular cereal monoculture, is connected with a considerable increase in the weed cover and exposure to take-all root rot disease. As a result, this leads to an increased competitive advantage of weeds over cereals, which is manifested in a deteriorated growth of plants, lower spike density, lower weight of grain per spike, and as a result a reduced yield. Further consequences include worse technological quality of grain, and in particular a decrease in grain weight per volume, worse grain plumpness and uniformity, as well as a higher content of ash in grain $[7,21,36]$. In our studies, crop sequence (CS) and tillage systems (TS) also differentiated the content of protein in grain (Table 3).

The protein content was higher in grain from cereal monoculture than from crop rotation $\mathrm{A}$ and $\mathrm{B}$ and was 
Table 2. The yield of durum wheat grain in $\mathrm{tha}^{-1}$.

\begin{tabular}{|c|c|c|c|c|}
\hline \multirow{2}{*}{ Crop sequence (CS) } & \multicolumn{3}{|c|}{ Tillage systems (TS) } & Mean \\
\cline { 2 - 5 } & $\mathrm{CT}$ & $\mathrm{RT}$ & 3.02 & 3.51 \\
\hline Crop rotation A & 3.94 & 3.56 & 2.67 & 2.87 \\
\hline Crop rotation B & 3.13 & 2.87 & 2.23 & 2.33 \\
\hline Cereal monoculture & 2.43 & 2.34 & 2.62 & - \\
\hline Mean & 3.17 & 2.92 & \\
\hline
\end{tabular}

Crop rotation A: pea - durum wheat - spring wheat; crop rotation B: pea - spring wheat - durum wheat; cereal monoculture: spring barley - spring wheat - durum wheat; CT - conventional tillage; RT - reduced tillage; NT - no-tillage; ns - not significant; $p<0.05$

Table 3. \% content of total protein in durum wheat grain.

\begin{tabular}{|c|c|c|c|c|}
\hline \multirow{2}{*}{ Crop sequence (CS) } & \multicolumn{3}{|c|}{ Tillage systems (TS) } & \multirow{2}{*}{ Mean } \\
\cline { 2 - 5 } & $\mathrm{CT}$ & $\mathrm{RT}$ & 15.6 & 15.5 \\
\hline Crop rotation A & 15.5 & 15.5 & 15.6 & 15.4 \\
\hline Crop rotation B & 15.4 & 15.3 & 15.5 & 15.6 \\
\hline Cereal monoculture & 15.7 & 15.5 & 15.6 & - \\
\hline Mean & 15.5 & 15.4 & \\
\hline \multicolumn{2}{|c|}{ HSD $_{0.05}$ for CS $=0.07, \mathrm{TS}=0.07 ; \mathrm{CS} \times \mathrm{TS}=0.16$} \\
\hline
\end{tabular}

Explanations under Table 2; ns - not significant, $p<0.05$

higher in NT than CT and RT. A higher protein content was also characteristic of grain for crop rotation B under NT than under CT and RT, as well as for monoculture under CT than under RT and NT. The content of wet gluten was higher in wheat grain harvested from crop rotation $\mathrm{A}$ and from cereal monoculture than from crop rotation $\mathrm{B}$ and was higher under NT than under CT (Table 4).

The value of sedimentation index was higher in grain harvested from cereal monoculture than from crop rotation A and B (Table 5). In addition, the value of this characteristic was further increased by the NT system for crop rotation $\mathrm{B}$, as compared to $\mathrm{RT}$, as well as CT system for cereal monoculture with reference to RT.
On the other hand, the content of starch in grain was independent of CS and TS (Table 6). The highest grain weight per volume was recorded for crop rotation A. It was significantly lower for crop rotation B, while the lowest was for cereal monoculture. The value of this characteristic also differed depending on the soil tillage system, with it being higher under CT than under RT and NT (Table 7). Despite a high content of protein and gluten and a high sedimentation index, the grain from cereal monoculture was characterized by low weight per volume, and hence by poor uniformity and, as a consequence, worse technological quality than the grain from crop rotation. Also under the CT system the grain had a higher weight per volume than under NT and RT

Table 4 . The $\%$ content of wet gluten in durum wheat grain.

\begin{tabular}{|c|c|c|c|c|}
\hline \multirow{2}{*}{ Crop sequence (CS) } & \multicolumn{3}{|c|}{ Tillage systems (TS) } & \multirow{2}{*}{ Mean } \\
\cline { 2 - 5 } & $\mathrm{CT}$ & $\mathrm{RT}$ & 31.5 & 30.8 \\
\hline Crop rotation A & 30.4 & 30.4 & 28.2 & 28.5 \\
\hline Crop rotation B & 28.3 & 29.0 & 31.6 & 30.9 \\
\hline Cereal monoculture & 30.4 & 30.6 & 30.4 & - \\
\hline Mean & 29.7 & 30.0 & $\mathrm{~N}$ \\
\hline
\end{tabular}

Explanations under Table 2; ns - not significant, $p<0.05$ 
Table 5. Zeleny sedimentation index of durum wheat grain in $\mathrm{mL}$.

\begin{tabular}{|c|c|c|c|c|}
\hline \multirow{2}{*}{ Crop sequence (CS) } & \multicolumn{3}{|c|}{ Tillage systems (TS) } & \multirow{2}{*}{ Mean } \\
\cline { 2 - 5 } & $\mathrm{CT}$ & $\mathrm{RT}$ & 61.6 & 61.8 \\
\hline Crop rotation A $^{\mathrm{a}}$ & 61.7 & 62.1 & 63.0 & 62.1 \\
\hline Crop rotation B & 61.7 & 61.6 & 63.4 & 63.4 \\
\hline Cereal monoculture & 64.1 & 62.7 & 62.7 & - \\
\hline Mean & 62.5 & 62.1 & \\
\hline
\end{tabular}

Explanations under Table 2; ns - not significant, $p<0.05$

and showed a similar content of protein and gluten, which may testify to its better suitability for semolina production [7].

The assessment of the variance components indicates that grain yield, gluten content, sedimentation value and grain weight per volume were to a larger extent affected by CS than by TS, whereas the protein content was to a larger extent affected by TS than by CS (Table 8).

Economic assessment. A significant aspect of the studies was an assessment of the economic effects of durum wheat production depending on the soil tillage system and on the crop sequence. The profitability of cereal production depends on the crop yield and on the level of grain prices and costs of production [37].
In a market economy costs are an important criterion for making decisions related to governance. However, their level is also determined by external (exogenous) factors, e.g., prices of the means of production [19, 24-25].

The first of the analyzed economic categories was the gross margin per 1 ha of crops (Table 9). This is the difference between the value of production and the direct costs of production, hence the cost of fuel was not included in this calculation.

The presented data indicates that the highest gross margin (393.7 EUR ha ${ }^{-1}$ ) was achieved for conventional tillage with crop rotation A (pea - durum wheat spring wheat). Irrespective of the soil tillage system,

Table $6 . \%$ content of starch in durum wheat grain.

\begin{tabular}{|c|c|c|c|c|}
\hline \multirow{2}{*}{ Crop sequence (CS) } & \multicolumn{3}{|c|}{ Tillage systems (TS) } & \multirow{2}{*}{ Mean } \\
\cline { 2 - 5 } & CT & RT & 49.6 & 48.6 \\
\hline Crop rotation A & 47.1 & 49.3 & 49.3 & 49.5 \\
\hline Crop rotation B & 49.3 & 50.0 & 49.2 & 49.0 \\
\hline Cereal monoculture & 48.6 & 49.4 & 49.3 & - \\
\hline Mean & 48.3 & 49.6 & \\
\hline \multicolumn{2}{|r|}{ HSD $_{0.05}$ for CS $=\mathrm{ns}, \mathrm{TS}=\mathrm{ns} ; \mathrm{CS} \times \mathrm{TS}=\mathrm{ns}$} \\
\hline
\end{tabular}

Explanations under Table 2; ns - not significant, $p<0.05$

Table 7. Durum wheat grain weight per volume in $\mathrm{kg} \mathrm{hL}^{-1}$.

\begin{tabular}{|c|c|c|c|c|}
\hline \multirow{2}{*}{ Crop sequence (CS) } & \multicolumn{3}{|c|}{ Tillage systems (TS) } & Mean \\
\cline { 2 - 5 } & $\mathrm{CT}$ & $\mathrm{RT}$ & 74.6 & 75.9 \\
\hline Crop rotation A & 77.3 & 75.8 & 73.3 & 74.6 \\
\hline Crop rotation B & 76.0 & 74.4 & 72.4 & 72.5 \\
\hline Cereal monoculture & 73.9 & 71.3 & 73.5 & - \\
\hline Mean & 75.7 & 73.8 & $\mathrm{n}$ \\
\hline \multicolumn{2}{|r|}{ HSD $_{0.05}$ for CS $=1.00, \mathrm{TS}=1.00 ; \mathrm{CS} \times \mathrm{TS}=\mathrm{ns}$} \\
\hline
\end{tabular}


Table 8. Analysis of variance for durum wheat grain yield and quality.

\begin{tabular}{|c|c|c|c|c|}
\hline Specification & Value & CS & TS & CS $\times$ TS \\
\hline \multirow{2}{*}{ Grain yield } & $F$ & 31.94 & 6.83 & 1.05 \\
\cline { 2 - 5 } & $p$ & $* *$ & $* *$ & $\mathrm{~ns}$ \\
\hline \multirow{2}{*}{ Total protein } & $F$ & 14.23 & 19.61 & 9.33 \\
\cline { 2 - 5 } & $p$ & $* *$ & $* *$ & $* *$ \\
\hline \multirow{2}{*}{\begin{tabular}{c} 
Wet gluten \\
\cline { 2 - 5 }
\end{tabular}} & $F$ & 82.96 & 5.49 & 4.03 \\
\hline \multirow{2}{*}{$\begin{array}{c}\text { Sedimenta- } \\
\text { tion index }\end{array}$} & $F$ & 25.73 & 3.03 & 5.60 \\
\cline { 2 - 5 } & $p$ & $* *$ & $\mathrm{~ns}$ & $*$ \\
\hline \multirow{2}{*}{$\begin{array}{c}\text { Starch con- } \\
\text { tent }\end{array}$} & $F$ & 0.37 & 0.88 & 0.29 \\
\cline { 2 - 5 } & $p$ & $\mathrm{~ns}$ & $\mathrm{~ns}$ & $\mathrm{~ns}$ \\
\hline \multirow{2}{*}{$\begin{array}{c}\text { Grain weight } \\
\text { per volume }\end{array}$} & $F$ & 37.09 & 18.84 & 1.74 \\
\cline { 2 - 5 } & $p$ & $* *$ & $* *$ & $\mathrm{~ns}$ \\
\hline
\end{tabular}

$\mathrm{CS}$ - crop sequence; TS - tillage systems; ns - not significant; ${ }^{*}-p<0.05,{ }^{*}{ }^{*}-p<0.01$

such crop rotation provided a relatively good gross margin averaging at 308.1 EUR ha-1. Crop rotation B (pea - spring wheat - durum wheat) was most favourable when conventional tillage was used. On the other hand, durum wheat monoculture resulted in the lowest gross margin, ranging from 108.9 EUR ha-1 for conventional tillage to $59.7 \mathrm{EUR} \mathrm{ha}^{-1}$ for the NT system.
An important economic category used in the evaluation of production profitability in agriculture is the income from activity constituting the difference between the value of production and overall costs. With regard to the possibility that the farmer can receive direct payments, this category was calculated taking the payments into account. In addition, the report of the European Commission [38] indicates that the production of durum wheat without direct payments would not be profitable. This is due to a relatively high production cost and low crop yield. The studies by Kleinhanss et al. [39] indicate that the costs for durum wheat per tonne in Italy are almost double those of soft wheat.

The study results presented in Table 10 lead to a conclusion that the most profitable cropping system was conventional tillage with crop rotation A. In that case, income per 1 ha of the crops reached 363.4 EUR, whereas in the least profitable variant it was only 57.3 EUR ha ${ }^{-1}$ (NT and cereal monoculture). Income exceeding 200 EUR ha $^{-1}$ was achieved for all soil tillage systems with crop rotation A and for conventional tillage using crop rotation B.

Cereal monoculture generated low income due to relatively low yield. Also Berzsenyi et al. [40], in their studies, found that wheat yield was in every case lower for monoculture than for crop rotation. Even the NT system, despite lower indirect costs did not contribute to increasing the income due to the low yield level. NT is a better system for warm regions with low precipitation sums (up to $300 \mathrm{~mm}$ ). In Central and Northern Europe, CT is more effective than NT.

Table 9. Gross margin per 1 ha of durum wheat crops (EUR ha-1).

\begin{tabular}{|c|c|c|c|c|}
\hline \multirow{2}{*}{ Crop sequence (CS) } & \multicolumn{3}{|c|}{ Tillage systems (TS) } & \multirow{2}{*}{ Mean } \\
\cline { 2 - 5 } & CT & RT & 208.7 & 308.1 \\
\hline Crop rotation A & 393.7 & 322.0 & 142.7 & 191.8 \\
\hline Crop rotation B & 240.9 & 191.9 & 59.7 & 86.8 \\
\hline Cereal monoculture & 108.9 & 91.9 & 137.0 & - \\
\hline Mean & 247.8 & 201.9 & \\
\hline
\end{tabular}

Explanations under Table 2

Table 10. Income including payments per 1 ha of durum wheat crops (EUR ha-1).

\begin{tabular}{|c|c|c|c|c|}
\hline \multirow{2}{*}{ Crop sequence (CS) } & \multicolumn{3}{|c|}{ Tillage systems (TS) } & \multirow{2}{*}{ Mean } \\
\cline { 2 - 5 } & CT & RT & 206.3 & 294.1 \\
\hline Crop rotation A & 363.4 & 312.5 & 140.3 & 177.7 \\
\hline Crop rotation B & 210.6 & 182.3 & 57.3 & 72.7 \\
\hline Cereal monoculture & 78.6 & 82.4 & 134.6 & - \\
\hline Mean & 217.5 & 192.4 & \\
\hline
\end{tabular}

Explanations under Table 2 
Table 11. Production profitability ratio - including the payments (\%).

\begin{tabular}{|c|c|c|c|c|}
\hline \multirow{2}{*}{ Crop sequence (CS) } & \multicolumn{3}{|c|}{ Tillage systems (TS) } & \multirow{2}{*}{ Mean } \\
\cline { 2 - 5 } & CT & RT & 141.6 & 158.2 \\
\hline Crop rotation A & 169.8 & 163.2 & 128.3 & 135.2 \\
\hline Crop rotation B & 140.5 & 136.9 & 111.5 & 114.4 \\
\hline Cereal monoculture & 115.1 & 116.7 & 127.1 & - \\
\hline Mean & 141.8 & 138.9 & \\
\hline
\end{tabular}

Explanations under Table 2

The above observations are supported by the level of the profitability ratio (Table 11). However, taking the direct payments into account, each of the analyzed cropping patterns was profitable, monoculture was the least profitable, i.e. from $111.5 \%$ (under NT) to $115.1 \%$ (under CT).

The production profitability ratio without direct payments for monoculture under all the analysed soil tillage systems was lower than $90 \%$, which means that production without the payments would be unprofitable. The mean level of profitability of durum wheat production for crop rotation $\mathrm{A}$ was $158.2 \%$, for crop rotation B - $135.2 \%$ and for monoculture $-114.5 \%$. Higher grain buying prices enhance the profitability of durum wheat production. As recounted by Sall et al. [41], the prices of this cereal range from 20 to $40 \%$ higher than the prices of ordinary wheat. However, according to the studies, were it not for direct payments, even a higher price would not compensate for a lower yield of durum wheat. Their relevance to decisions related to production and to achieving adequate profitability of durum wheat production is also recognized by Siad et al. [19].

\section{Conclusions}

Studies show that conventional tillage with crop sequence: pea - durum wheat - spring barley resulted in the highest crop yield. In the case of a conventional tillage system, the yield was on average 17.3\% higher than in the case of no tillage. In addition, it was found that the content of protein and wet gluten in the grain changed depending on the crop sequence and soil tillage system. Studies have shown that, from an economic point of view, wheat should be preferably grown using the conventional tillage system (CT) and crop rotation: pea - durum wheat - spring wheat. The studies also revealed that monoculture was not profitable, even with the no-tillage system. However, taking the direct payments into account, each of the analyzed cropping patterns was profitable, monoculture was the least profitable. The studies do not touch upon all the aspects of durum wheat production. Further research should aim at minimizing the negative effect of the cultivation on the environment, maintaining high yield and proper quality of grain. At the same time, a preferred solution is the rotation of crops involving structure-forming plants and the optimization of soil tillage. Thus, it can be concluded that especially farms featuring a diversified production structure are predisposed to growing durum wheat. Such a management strategy is characteristic, in particular, of countries with fragmented agrarian structure, including Poland and most member states that joined the European Union in 2004 and later. This is due to the facilitated selection of crops for rotation in specialised farm more often relying on monoculture production. Such a direction of production is also consistent with the strategy of sustainable agriculture aiming, inter alia, to promote crop rotation.

\section{Acknowledgements}

Research supported by Poland's Ministry of Science and Higher Education as part of the statutory activities of the Department of Herbology and Plant Cultivation Techniques and Department of Economics and Agribusiness, University of Life Sciences in Lublin.

\section{Conflict of Interest}

The authors declare no conflict of interest.

\section{References}

1. GRUBER S., PEKRUN C., MÖHRING J., CLAUPEIN W. Long-term yield and weed response to conservation and stubble tillage in SW Germany. Soil and Tillage Research, 121, 49, 2012.

2. HALINIARZ M., NOWAK A., WOŹNIAK A., SEKUTOWSKI T.R., KWIATKOWSKI C.A. Production and economic effects of environmentally friendly spring wheat production technology. Polish Journal of Environmental Studies, 27, 1523, 2018.

3. WOŹNIAK A. Effect of crop rotation and cereal monoculture on the yield and quality of winter wheat grain and on crop infestation with weeds and soil properties. International Journal of Plant Production, 13, 177, 2019. 
4. DE VITA P., DI PAOLO E., FECONDO G., DI FONZO N., PISANTE M. No-tillage and conventional tillage effects on durum wheat yield, grain quality and soil moisture content in Southern Italy. Soil and Tillage Research, 92, 69, 2007.

5. MAŁECKA I., BLECHARCZYK A. Effect of tillage systems, mulches and nitrogen fertilization on spring barley (Hordeum vulgare). Agronomy Research, 6 (2), 517, 2008.

6. MAL P., SCHMITZ M., HESSE J.W. Economic and environmental effects of conservation tillage with glyphosate use: A case study of Germany. Outlooks on Pest Management, 26, 24, 2015.

7. WOŹNIAK A., STĘPNIOWSKA A. Yield and quality of durum wheat grain in different tillage systems. Journal of Elementology, 22, 817, 2017.

8. HERNANZ J.L., SÁNCHEZ-GIRÓN V., NAVARRETE L., SÁNCHEZ M. J. Long-term (1983-2012) assessment of three tillage systems on the energy use efficiency, crop production and seeding emergence in a rain fed cereal monoculture in semiarid conditions in central Spain. Field Crops Research, 166, 26, 2014.

9. LOCKE M.A., REDDY K.N., ZABLOTOWICZ R.M. Weed management in conservation crop production systems. Weed Biology and Management, 2, 123, 2002.

10. MEHMETI A., PACANOSKI Z., FETAHAJ R., KIKA A., KABASHI B. Weed control in wheat with post-emergence herbicides. Bulgarian Journal of Agricultural Science, 24, 74, 2018.

11. KONING L.A., DE MOL F., GEROWITT B. Effects of management by glyphosate or tillage on the weed vegetation in a field experiment. Soil and Tillage Research, 186, 79, 2019.

12. BAI G., SHANER G. Management and resistance in wheat and barley to Fusarium head blight. Annual Review of Phytopathology, 42, 135, 2004.

13. SIELING K., STAHL C., WINKELMANN C., CHRISTEN O. Growth and yield of winter wheat in the first 3 years of a monoculture under varying $\mathrm{N}$ fertilization in NW Germany. European Journal of Agronomy 22, 71, 2005.

14. TILLMANN M., VON TIEDEMANN A., WINTER M. Crop rotation effects on incidence and diversity of Fusarium species colonizing stem bases and grains of winter wheat. Journal of Plant Diseases and Protection. New Series, 124 (2), 121, 2017.

15. RAMANAUSKIENE J., SEMAŠKIENE R., JONAVIČIENĖ A., RONIS A. The effect of crop rotation and fungicide seed treatment on take-all in winter cereals in Lithuania. Crop Protection, 110, 14, 2018.

16. ANDRADE O., CAMPILlO R., PEYRELONGUE A., BARRIENTOS L. Soils suppressive against Gaeumannomyces graminis var. tritici identified under wheat crop monoculture in southern Chile. Ciencia e Investigacion Agraria, 38 (3), 345, 2011.

17. GUTTERIDGE R. J., HORNBY D. Effects of sowing date and volunteers on the infectivity of soil infested with Gaeumannomyces graminis var. tritici and on takeall disease in successive crops of winter wheat. Annals of Applied Biology, 143 (3), 27, 2003.

18. VASILIEV N., ASTOVER A., ROOSTALU H., MATVEEV E. An agro-economic analysis of grain production in Estonia after its transition to market economy. Agronomy Research, 4 (1), 99, 2006.

19. SIAD S.M., GIOIA A., HOOGENBOOM G., IACOBELLIS V., NOVELLI A., TARANTINO E.,
ZDRULI, P. Durum wheat cover analysis in the scope of policy and market price changes: a case study in Southern Italy. Agriculture, 7, 12, 2017.

20. LITKE L., GAILE Z., RUŽA A. Effect of nitrogen fertilization on winter wheat yield and yield quality. Agronomy Research, 16 (2), 500, 2018.

21. ZARGAR M., POLITYKO P., PAKINA E., BAYAT M., VANDYSHEV V., KAVHIZA N., KISELEV E. Productivity, quality and economics of four spring wheat (Triticum aestivum L.) cultivars as affected by three cultivation technologies. Agronomy Research, 16 (5), 2254, 2018.

22. JAT R.K., SAPKOTA T.B., SINGH R.G., JAT M.L., KUMAR M., GUPTA R.K. Seven years of conservation agriculture in a rice-wheat rotation of eastern Gangetic Plains of South Asia: yield trends and economic profitability. Field Crops Research, 164, 199, 2014.

23. FALCONE G., STILLITANO T., MONTEMURRO F., DE LUCA A.I., GULISANO G., STRANO A. Environmental and economic assessment of sustainability in Mediterranean wheat product. Agronomy Research, 17 (1), 60, 2019.

24. VACH M., STRAŠIL Z., JAVŮREK M. Economic efficiency of selected crops cultivated under different technology of soil tillage. Scientia Agriculturae Bohemica, 47 (1), 40, 2016.

25. SKARŻYŃSKA A. Unit costs and income from selected products in 2016 - research results in the Agrokoszty System. Problems of Agricultural Economics, 2 (355), 137, 2018.

26. LIDON C. F., ALMEIDA A. S., LEITÃO SILVA M. M., PINHEIRO N., BENVINDO MAÇÃS B., COSTA R. A synoptic overview of durum wheat production in the Mediterranean region and processing following the European Union requirements. Emirates Journal of Food and Agriculture, 26 (8), 693, 2014.

27. WRB, World reference base for soil resources 2014. International soil classification system for naming soils and creating legends for soil maps. World Soil Resources Reports No. 106, update 2015. FAO: Rome, Italy, 203, 2014.

28. MEIER U. Growth stages of mono-and dicotyledonous plants. BBCH Monograph. Federal Biological Research Centre for Agriculture and Forestry: Berlin and Braunschweig, Germany, 158, 2001.

29. GORAJ L., MAŃKO S. Accounting and economic analysis in an individual farm. Difin: Warsaw, Poland, pp. 267, 2009 [In Polish].

30. SKARŻYŃSKA A., ABRAMCZUK Ł., JABŁOŃSKI $\mathrm{K}$. Impact of growing costs on the profitability of crop production in Poland in the mid-term perspective. Journal of Central European Agriculture, 17 (1), 119, 2016.

31. SKARŻYNSSKA A. Costs and profitability, unit costs and income from selected products in 2017 - research results in the Agrokoszty System. Problems of Agricultural Economics, 2 (359), 100, 2019.

32. JABŁOŃSKI K., SKARŻYŃSKA A., ABRAMCZUK Ł. Determinants of income from wheat and rape production in projection for 2020 in Poland. Žemès ūkio mokslai, 22 (4), 229, 2015.

33. SMAGACZ J., KOZIEŁ M., MARTYNIUK S. Soil properties and yields of winter wheat after long-term growing of this crop in two contrasting rotations. Plant, Soil and Environment, 62 (12), 566, 2016.

34. MORRISON M.J., COBER E.R., GREGORICH E.G., VOLDENG H.D., MA B., TOPP G.C. Tillage and crop 
rotation effects on the yield of corn, soybean, and wheat in eastern Canada. Canadian Journal of Plant Science, 98 (1), 183, 2018.

35. GUTTERIDGE R.J., JENKYN J.F., BATEMAN G.L. Effects of different cultivated or weed grasses, grown as pure stands or in combination with wheat, on take-all and its suppression in subsequent wheat crops. Plant Pathology, 55, 696, 2006.

36. RACHOŃ L., SZUMIŁO G., BRODOWSKA M., WOŹNIAK A. Nutritional value and mineral composition of grain of selected wheat species depending on the intensity of a production technology. Journal of Elementology, 20 (3), 705, 2015.

37. BOR O., BAYANER A. How responsive is the crop yield to producer prices? A panel data approach for the case of Turkey. New Medit, 8 (4), 28, 2009.

38. EUROPEAN COMMISSION. EU cereal farms report 2012 based on FADN data. European Commission Directorate-
General for Agriculture and Rural Development: Brussels, Belgium, 110, 2013.

39. KLEINHANSS W., OFFERMANN F., BUTAULT J.P., SURRY Y. Cost of production estimates for wheat, milk and pigs in selected EU member states. Arbeitsberichte aus der vTI-Agrarökonomie. Institute of Farm Economics, Working Paper N. 07: Braunschweig, Germany, 68, 2011.

40. BERZSENYI Z., GYORFFY B., LAP D.Q. Effect of crop rotation and fertilisation on maize and wheat yields and yield stability in a long-term experiment. European Journal of Agronomy, 13, 225, 2000.

41. SALL A. T., CHIARI T., LEGESSE W., SEID-AHMED K., ORTIZ R., VAN GINKEL M., BASSI F.M. Durum wheat (Triticum durum Desf.): origin, cultivation and potential expansion in Sub-Saharan Africa. Agronomy, 9, 263, 2019. 